\title{
Professional Training in Educational Sports in Brazil: The Collaborating Teams of the Programa Segundo Tempo (PST) - Federal Government
}

\author{
Formação Profissional em Esporte Educacional no Brasil: As Equipes Colaboradoras do Programa \\ Segundo Tempo (PST) - Governo Federal
}

Formación Profesional en Deportes Educativos en Brasil: Los Equipos Colaboradores del Programa Segundo Tempo (PST) - Gobierno Federal

\author{
Sheylazarth Presciliana Ribeiro \\ ORCID: https://orcid.org/0000-0003-4768-9135 \\ Universidade do Estado de Minas Gerais, Brazil \\ E-mail: sheylazarth.ribeiro@uemg.br \\ Ana Cláudia Porfírio Couto \\ ORCID: https://orcid.org/0000-0003-3457-0987 \\ Universidade Federal de Minas Gerais, Brazil \\ E-mail: acpcouto@gmail.com
}

\begin{abstract}
PST is a public educational sport policy of the Brazilian Federal Government for the promotion of educational sports by the Ministry of Sport (2003-2018) with the support of the Collaborating Teams. The purpose of this article is to describe who these teams were, how educational sport was thought of by them, and how these Collaborating Teams approached teachers of Physical Education who worked in educational sport centers (Core Coordinators). For description and analysis, we used the literature review with the subject of professional training, educational sport and Programa Segundo Tempo [Second Time Program] and we count on documental analysis by Bardin (2011). We have conclude that the Collaborating Teams show the possibility of intervening in the training of Core Coordinators throughout the country, and for that, these Teams were formed by trainers (university professors) who worked in the search for dialogue with the Coordinators of Sports Core. This dialogue has the potential to reinvent sport, from a traditional sport to an educational sport aiming to ensure the rights of children and adolescents to access sport and leisure in Brazil.
\end{abstract}

Keywords: Professional training; Educational Sport; Programa Segundo Tempo; Teaching.

\begin{abstract}
Resumo
O PST é uma política pública do Governo Federal Brasileiro para promoção do esporte educacional, e a gestão de 2003 até 2018 pelo extinto Ministério dos Esportes promoveu uma Capacitação de professores em Esporte Educacional pelas Equipes Colaboradoras -ECs. Esse artigo tem o objetivo de descrever e analisar as ECs quanto aos formadores dos cursos, a prática de esporte nomeado de educacional e as ECs como grupos de formadores/professores universitários com potencial de diálogo com os Coordenadores de Núcleos Esportivos - CNs. Para descrição e análise usamos a revisão de literatura com a temática de formação profissional em esporte e lazer, esporte educacional e o Programa Segundo Tempo e contamos com análise documental de Bardin (2011). Concluímos que as ECs mostram a possibilidade de uma intervenção universitária na formação esportiva em todo o país, e para isso os formadores são em 2012190 professores universitários de todo o país e diferentes áreas da Educação Física organizados em 33 equipes. As ECs trabalhavam com o esporte educacional como prática esportiva de ressignificação de um esporte excludente em esporte democrático. Por fim, as ECs se dedicavam a dialogar com os CNs como apoio a prática pedagógica esportiva.
\end{abstract}

Palavras-chave: Formação profissional; Esporte Educacional; Programa Segundo Tempo; Ensino.

\section{Resumen}

El PST es una política pública del Gobierno Federal de Brasil para la promoción del deporte educativo, y la gestión de 2003 a 2018 por el ahora desaparecido Ministerio de Deportes promovió una formación de profesores en Deporte Educativo por parte de los Equipos Colaboradores -ECs. Este artículo tiene como objetivo describir y analizar las EC con respecto a los entrenadores del curso, la práctica del deporte nombrado educativo y las ECs como grupos de entrenadores / profesores universitarios con potencial de diálogo con los Coordinadores de Centros Deportivos - CNs. Para la descripción y el análisis se utilizó la revisión bibliográfica con el tema de la formación profesional en deportes y ocio, el deporte educativo y el Programa de Segunda Vez y contamos con análisis documental de Bardin (2011). 
Concluimos que las ECs muestran la posibilidad de una intervención universitaria en la educación deportiva en todo el país, y para ello los entrenadores son en 2012190 profesores universitarios de todo el país y diferentes áreas de la Educación Física organizados en 33 equipos. Las EC trabajaron con el deporte educativo como una práctica deportiva de resignificación de un deporte excluyente en el deporte democrático. Por último, las EC se dedicaron al diálogo con las EC en apoyo de la práctica educativa.

Palabras clave: Formación profesional; Deporte Educativo; Programa Segundo Tempo; Enseñanza.

\section{Introduction}

The Brazilian government in the years 2003 to 2018 had in its structure a Ministry of Sports, which among its actions promoted a sports policy entitled Programa Segundo Tempo - PST. For 15 years, this public policy dealt with the development of Educational Sports in the country, which consisted of studying the concept, how it would be implemented in different municipalities, how it would be evaluated and how it would be disseminated.

Educational Sport, different from Physical Education at School, is a pedagogical practice taking sport as an instrument to achieve fundamental elements of citizenship and human development. It inhibits sports practices aiming only at high performance and values pedagogical actions promoting respect for differences and the participation of subjects who are usually socially excluded. Although educational sports can be implemented in schools, community sports facilities are privileged spaces for its promotion.

The Ministry of Sports articulated with Higher Education Institutes (IES) from different parts of the Brazilian territory and created the Collaborating Teams in 2008 to implement professional training. These teams had the attribution of dialoguing with Physical Education teachers who worked in the PST (Core Coordinators) and evaluating the development of educational sports in the communities served.

This article aims to describe and analyze the work of the Collaborating Teams regarding their constitution, the understanding of educational sport and the methodologies of action with the Core Coordinators of PST.

The relevance of recording actions of the Federal Government added to some Brazilian Higher Education Institutes lies in the construction of a memory of possible intervention in sports policy. The article analyzes a methodology for the application of professional training for sport and leisure in the country, and presents reflections on educational sport as an intervention/break with traditional sports practices and teachers of the Collaborating Teams as advisors with potential for dialogue with the NCs to strengthening of these new sports practices.

\section{Methodology}

For description and analysis, we used a literature review with the theme of professional training in sport and leisure, educational sport and Programa Segundo Tempo. We have documental analysis of texts archived by the Memory Center of the Universidade Federal do Rio Grande do Sul [Federal University of Rio Grande do Sul] - UFGRS (2020a, 2020b, 2020c) that dealt with the work of the Collaborating Teams. And, as organizing method of writing, we were guided by (Bardin, 2011) document analysis, looking at the classification (videos, slides, interviews, books) and the purposes of the texts, creating a file for consultation and storage of information (Ribeiro, 2017).

For content analysis, we work with a focus on information as messages that can be organized into analytical categories. We have used the categories or subjects articulating the messages and ideas discussed in the selected literature reviews. This article is divided into: introduction; work and conclusion subjects. 


\section{Results and Discussion}

PST is a public policy of the Brazilian Federal Government that has been developed up to date, however, its administration from 2003 to 2018, by the Ministry of Sports, had the purpose of democratizing the access of children and young people to sport, and for that, signed an agreement with the municipalities and implemented educational sports centers. Those who worked in these spaces were the Core Coordinators and their pedagogical practice should have as a premise to ensure that every child participating would access different sports skills and competences without constraints regarding their skin color, social class, gender, religion, disabilities, etc.

Ribeiro \& Isayama (2015) show that in this program there was a Training process for Coordinators of Educational Sports Cores. The direct way to reach these workers was through dialogue with the Collaborating Teams. The latter were formed by professors linked to Collaborating Teams in Brazil, distributed in a territorially decentralized manner, who work to promote the encounter with several agreements signed between the federal government and the municipalities.

Starepravo, et. al. (2012) highlight that, in 2012, the Collaborating Teams consisted of 190 professionals from 33 Higher Education Institutions in different regions of the country. These Institutions acted in partnership with the former Ministry of Sports to monitor the process of training and monitoring the PST, creating a "Network" for reflection, training and evaluation of Educational Sports. According to the authors, the purpose of that monitoring "Network" would be to enhance and qualify both administrative and pedagogical actions of the PST Starepravo, et. al. (2012).

\subsection{Collaborating Teams and Universities}

In Brazil, the State is the main funder of public universities, in addition to this relationship, the university is understood as a locus of innovation. The articulation between the Federal Government and the university, in the last decade, has been strengthened in the area of sport and leisure. Innovation is understood as the result of a complex and continuous process of experiences in the relationships between science, technology, research and development in universities, companies and government. The university would be the basis for the production process of science and innovation, connecting to the institutions operating in society.

The university, in this regard, is not a closed world in itself, it dialogues with different instances of governments and other industries. As an example of the market-university-state relationship, we have junior companies and, among the university-government articulations, we have the management of public policies for the formation of sport and leisure.

Sport and leisure programs had professional training axes managed by federal universities. Capi (2016) shows how the Sports and Leisure Program of the City (PELC) had its professional training process organized by the partnership between the Ministry of Sports and the Universidade Federal de Minas Gerais [Federal University of Minas Gerais]. To manage the Training and the Memory collection of PST, the Ministry of Sports counted on the Universidade Federal do Rio Grande do Sul - UFRGS.

To set up the Collaborating Teams, UFGRS selected a group of teachers from institutions in different regions of the Brazilian territory linked to the area of Physical Education and set up groups generating the Teams. These university professors thought of the Training of the PST and were linked to the program for a remuneration scholarship. The Federal Government selected qualified people in the field of sports and related areas from different regions to compose the Collaborating Teams. Starepravo, et. al. (2012, p.134) show that:

As for the training/degree of the participants of ECs who answered the questionnaire, the data found were as follows: six $(8 \%)$ graduates, three (4\%) experts, six (8\%) students of Master's Degree, twenty-six $(34.7 \%)$ with Master's Degree, four (5.3\%) students of Ph.D., twenty-three (30.7\%) Ph.D.s and one (1.3\%) PHD. 
Each Team had a coordinator, a vice-coordinator and a number of trainers. These people are graduates, masters and Ph.D. in the field of Physical Education and related areas. According to Starepravo, et. al. (2012), the members worked in thirteen different areas of Physical Education, a factor that could contribute to different perspectives regarding the planning and evaluation of the PST in the regions of the country. These teachers were also distinct in terms of their regionalization, which, according to Starepravo, et. al. (2012) expands the epistemological diversity of Brazilian Physical Education within the PST. Still according to the authors, however, this same diversity constitutes a challenge, that of "harmonizing such diverse points of view on the same subject" (Starepravo, et. al., 2012, p.134).

The Teams worked with the Training of PST coordinators and monitors through a course given in person, after about a month they started working in the cores. In the course, the trainers use programmed methodologies as videos and texts to deal with the Program's pedagogical guidelines. According to Starepravo, et. al. (2012), the Teams believe that training directly reflects on the actions developed in the cores, the contribution of training is related to the development of classes in the cores, the theoretical foundation of the actions and the management of the cores. Also according to the teachers of the Teams, the training allows: contact with coordinators and monitors to remove doubts about the operation of the core; the agreements receive the support of the Federal Government; guide the use of management systems (Ferreira et. al., 2009); and benefit compliance with the terms of the agreements pursuant to guidelines.

According to Garanhani \& El Tassa (2013), a challenge for Team Training is "contributing to effective support for the pedagogical work of teachers and academics/monitors in the cores, in addition to enhancing the reflection of these professionals on their responsibility as a trainer of children, adolescents and young people in our country". Thus, the Collaborating Teams are composed of people who are artisans who work through the construction of meanings for the goals and sports practices proposed by the PST.

the role of trainers, in addition to providing knowledge about the pedagogical guidelines and orientations of PST, also helps teachers to contextualize, adapt and reframe them in the preparation of proposals complying with several sociocultural and economic aspects presented by the different cores of the program. For such, it is necessary not only training in the form of courses, which in the PST are called training, but training in context. (Garanhani \& El Tassa, 2013, p. 284).

The Collaborating Teams seek to build, together with the Core Coordinators, intervention proposals in the sports area, contextualizing the different realities surrounding the cores of Educational Sport. Teams must have trainers who are: symbolic analysts; artisans, as they are reinventers of practices; relationship professionals; and teachers are constructors of meaning (Garanhani \& El Tassa, 2013, p. 275).

Bisconsini, et al (2015) point out that with the emergence of the Distance Learning system in the Training of the PST, new forms of performance for the Team teachers were formed. Teachers needed to become distance training tutors to attend the Core Coordinators also virtually. The need for a tutor who recognized the virtual learning environment led the Ministry of Sports at that time to produce tutor courses for the Collaborating Teams.

In 2013, there were two training courses in a virtual environment aimed at training tutors. "Which made it possible for the members of the Collaborating Teams to organize themselves to adhere to the process, in addition, the members of the first group were able to return to the instrumentation to resolve possible doubts, in order to carry out the proposal." (Bisconsini, et. al., 2015). According to Bisconsini, et. al. (2015), the teachers of the Collaborating Teams had difficulties in using the virtual environment and they recognized this difficulty.

The Teams are composed of university professors from the physical education area who dialogue with the Core Coordinators through on-site courses and distance courses. The aim of these professors is to create strategies to understand the work context in the cores and help the Coordinators to reinvent sports practices. 


\subsection{Educational Sport and the Challenges of Training of Core Coordinators}

Sport can be understood as a social phenomenon that is linked to different areas, so it is possible to find studies on sport in the areas of sociology, history, law, communication, economics, education, among others. We understand that a privileged place to think about sport are the Physical Education courses in which sport is understood with intervention pedagogies in different spaces. These pedagogies are necessary due to sports practices promoting the exclusion of social minorities and those unilaterally anchored in physical performance and not considering sport as a social right, practices that were disseminated in the Brazilian territory and naturalized in our culture.

Educational sport advances in different methods from the traditional ones for the teaching of sport in Brazil, as Araújo, et. al. (2012) remind us, the public policy of the PST is a means that centralizes the transformations arising from the teaching of educational sport - Learning system and sport development (SADE) or EAT (Brasil, 2005). For the authors, SADE, chosen as the PST's working methodology, advances at the expense of the "schizophrenia of rehearsed plays and repetitions with a view to an ideal motor standard to consider the environmental aspects of sports practices and the educational value of the game." (Starepravo, et. al., 2012, p. 42). The emergence of qualification is due to the need to operationalize the change in the way of teaching sport in the centers, so it is designed with the Core Coordinator of PST as a receiver, as he/she is responsible for planning and executing the sports actions.

Dialogue with the Core Coordinators in Brazil with their regional specificities and the multiplicity of sports practices in the country (which is one of the issues that hinder the implementation of public educational sports policies) can be a challenge. Training in the area of Physical Education and consequently the way of seeing public policy are not unique. As an example, we have the work of Bezerra (2014), regarding the experience of the Training of the PST in the city of Riacho da Cruz/CE, the monitoring of the Collaborating Team was not enough to assist in the training of the Coordinators of the city with regard to transition from the Program's guidelines to practice in the cores.

Rodrigues, et. al. (2012) recognize that the Training model of PST has virtues and problems and propose a complement to training actions. The authors verify that the PST reproduces the training model of most undergraduate courses in Physical Education, in the technical-scientific model. The proposal of the authors would be to highlight the voice of the Core Coordinators through meetings organized in a progressive sequence of activities. Thus, they would be able to talk about their difficulties and produce ideas to overcome the challenges posed to the development of educational sport.

The Core Coordinators are often Physical Education teachers who already work in other school and non-school spaces with bodily practices, training is a meeting of people with different practical knowledge built by lived experiences (Bondia, 2002) on the day to day of the cores.

Ribeiro (2017) points out that the Core Coordinators attribute different meanings to the Training of the program, for some of them the experiences of some activities and exchange of experiences are important knowledge and the Training produces the sense of recycling knowledge. Other Core Coordinators indicate the importance of gender content affecting the daily life of the school and good materials used for the course. There are still those Coordinators for whom Training is mandatory and should be carried out even if the life organization of these Coordinators was committed to other activities other than the PST. Other coordinators believe that the course content is repetitive, or similar to graduation in Physical Education. (Ribeiro, 2017).

The core Coordinators and the authors studied point out that the training/educational sport courses had strengths and weaknesses, and working with this training was challenging. The trainers of the Collaborating Teams sought different ways to work with educational sport together with the core coordinators. 


\subsection{Trainers of educational sport and the advisory process}

The trainers of the Teams worked in an attempt to sensitize the Core Coordinators to Educational Sports that would encourage the improvement of pedagogical quality for teaching various bodily practices. The Teams produced educational and sports materials as well as assessment and monitoring strategies for the centers (lists of attendance, pedagogical plans for teaching sports, books with teaching content on various sports practices, etc.). Furthermore, the Teams valued actions of

c) Updating, in order to provide teachers in the area of physical education and/or sport with training that is adequate to the reality of the beneficiaries, allowing them to transmit knowledge and work on diversified motor experiences with their students; d) Dialogue, to encourage the integration of beneficiaries in the planning of activities, in the construction of a healthy collective life and in the resolution of conflicts, thus aiming to stimulate the social and political awareness of the new generations; e) Safety, in order to ensure that bodily practices within the scope of the Program take place with monitoring and that they protect the integrity of the children and adolescents served (Brasil, 2017).

The Guidelines (Brasil, 2017) also address that "at the end of training, coordinators and teachers must recognize the central principles of the PST, its theoretical foundations and master how these guide pedagogical practices in serving beneficiaries".

Recognizing training in educational sport as a challenge to be faced, the field of Education has a collection of theoretical models to problematize continuing education. Among these, Imbernón (2011) speaks of the process of training or training teachers also as an advisory process.

In the educational field, the advisory process is very recent and with this, it has other fields of knowledge to think about the teacher's trainer in continuing education. For the author, the teacher training process is not a control of knowledge, but an instrument of improvement producing different types of advice.

The author shows how, in the field of education, advisors began to suffer from the difficulty of theoretically training and forgot that the figure of the advisor comes from the same practice as the teacher and can build a process of mutual help. In the 1990s, the concept of expert advice, whose knowledge would be infallible, surfaced in a proposal of technical rationality.

The teacher advisory process should intervene based on the demands of teachers or educational institutions with the aim of helping in problem situations involving teachers in a process of commitment to reflection on action. It is about transforming into process advisors, or mediators between knowledge and the group.

Imbernón (2011) also leaves data that could be transposed to the training of Core Coordinators of Educational Sport. According to the author

There are international experiences of training advisors who agree that this training should be based on preparation in dealing with groups, identification of needs, adult learning techniques (which is not traditional work and has differences with the school education process as teachers have more homogeneity and more level), the adoption of learning techniques, the improvement of skills (especially in structuring problems) and in the reflection and evaluation of training processes. (p. 95)

The role of the advisor is to stand side by side with teachers undergoing permanent training, breaking with the idea of the infallible specialist. For him, the role of the advisor is to understand the obstacles that teachers face in reaching their "own contextualized solution". Imbernón $(2011,2010)$ shows how this service has become the doctor-patient model, in which the advisor expects professors to trust their superior knowledge and wisdom to solve problems; Approaches communication in one direction only, speaks and prescribes while the teacher listens and obeys; understands the situation only in the form he dominates; and applies expert knowledge more intuitively than reflectively.

Adding to the work of Garanhani \& El Tassa (2013), we understand that working in a Collaborating Team is a challenging task, as it directly intervenes in the work of another. In this regard, the literature suggesting this formative work 
should be done by listening to educational sport promoters, trying to understand the daily challenges of these practices in the core and cause the Core Coordinators to think about their intervention possibilities and possible solutions.

\section{Conclusion}

Brazil is a country with large territorial dimensions that, in the years 2003 to 2018, promoted professional training actions in the field of educational sport as an axis of sport and leisure policy. The trainings of PST were challenging because they addressed the transformation of sports practices based only on technical and tactical development for sports practices that were the right of all children and young people in the communities served.

As a training strategy, the Brazilian Federal Government articulated partnerships with Universities, setting up Collaborating Teams that created strategies to approach the Core Coordinators of Educational Sports. The production of videos, books, academic research, memory collections, distance study platforms, assessment systems and in-person courses were media built by the Collaborating Teams for this Training.

Professional training in sport and leisure still has its challenges as exposed in this article, however, ideas from other studies on teacher training can add to possible solutions. The approach of researcher Imbernón (2010; 2011) on advisory and interventions in teaching has innovative characteristics for the approach of professionals in training.

We believe in the fruitful partnership between Governments and Universities to promote social rights and expand the exercise of citizenship. In this regard, studies helping to reflect on these articulations can potentialize future actions dedicated to promoting the democratization of sport and leisure in Brazil.

In future work, investigating the Collaborating Teams and principles proposed by the ME, as periodically participating in National Meetings, might prove important. These moments were attempts to articulate the group regarding the PST guidelines and, at the same time, evaluate and align the evaluation processes, as on-site visits and their reports, Training, evaluation of the Core's Pedagogical Programs (PPN) etc. The search for the articulation of the group is herein understood as this process of centralizing and creating a language that organizes guidelines on the execution of the PST with partner entities, both in its administrative and pedagogical nature.

\section{References}

Araújo, A. C., Cavalcanti, L. M. B., Tassitano, R. M., de Lacerda, E. P., \& Tenório, M. C. M. (2012). Formação e atuação pedagógica no Programa Segundo Tempo: reflexões sobre o fazer cotidiano do professor. Motrivivência, (38), 40-58. Doi: https://doi.org/10.5007/2175-8042.2012v24n38p40

Bezerra, J. C. (2014). Reflexões sobre o dito e o feito nas intervenções pedagógicas no Programa Segundo Tempo (Master's thesis, Universidade Federal do Rio Grande do Norte). https://repositorio.ufrn.br/handle/123456789/14623

Bisconsini, C. R., Anversa, A. L. B., de Oliveira, A. A. B., \& de Souza, V. D. F. M. (2015). Processo de formação continuada: a realidade de um programa social esportivo. Motrivivência, 27(46), 119-134. Doi: https://doi.org/10.5007/2175-8042.2015v27n46p119

Bondía, J. L. (2002). Notas sobre a experiência e o saber de experiência. Revista brasileira de educação, 20-28.

Brasil. Ministério do Esporte (2017). Programa Segundo $\quad$ Dempo http://www.esporte.gov.br/arquivos/snelis/2017/SegundoTempo/Diretrizes\%20Programa\%20Segundo\%20Tempo.pdf

Capi, A. H. C. (2016). Construção de Saberes sobre o Lazer nas Trajetórias de Formadores/as do Programa Esporte e Lazer da Cidade. LICERE-Revista do Programa de Pós-graduação Interdisciplinar em Estudos do Lazer, 19(3), 383-384. https://periodicos.ufmg.br/index.php/licere/article/view/1309

Cidade, R. E., Goellner, S. V., Soares, L. S., \& Carvalho, M. A. A. (2012). O acompanhamento operacional, pedagógico e administrativo dos convênios do Programa Segundo Tempo: equipe colaboradora. Goellner SV, Soares LS, Carvalho MAA. Programa Segundo Tempo: memória, experiências, avaliação e perspectivas no Encontro das Equipes Colaboradoras. Maringá: Eduem, 239-242. http://hdl.handle.net/10183/79102

Ferreira, H., Cassiolato, M., \& Gonzalez, R. (2009). Uma experiência de desenvolvimento metodológico para avaliação de programas: o modelo lógico do Programa Segundo Tempo. Brasília: Ipea. https://www.ipea.gov.br/portal/images/stories/PDFs/TDs/td_1369.pdf

Garanhani, M. C., \& El Tassa, K. O. M. (2013). Formação profissional para atuação em projetos sociais: no foco a formação de professores no" Programa Segundo Tempo". Movimento, 19(4), 273-287. https://www.redalyc.org/articulo.oa?id=115328881013 
Research, Society and Development, v. 11, n. 1, e0311124269, 2022

(CC BY 4.0) | ISSN 2525-3409 | DOI: http://dx.doi.org/10.33448/rsd-v11i1.24269

Imbernón, F. (2010). Formação continuada de professores. São Paulo: Artmed Editora.

Imbernón, F. (2001). Formação docente e profissional: formar-se para a mudança e a incerteza. São Paulo: Cortez.

Martín-Barbero, J. (1995). América Latina e os anos recentes: o estudo da recepção em comunicação social. Sujeito, o lado oculto do receptor. São Paulo: Brasiliense.

Ribeiro, S. P. (2017). Compreensões do lazer pelos coordenadores de núcleo do programa Segundo Tempo: mediações implicadas nas capacitações do programa. (Doctor's thesis, Programa de Pós-Graduação em Estudos do Lazer da Universidade Federal de Minas Gerais). http://hdl.handle.net/1843/BUOS$\mathrm{B} 2 \mathrm{CH} 3 \mathrm{Z}$

Ribeiro, S. P., \& Couto, A. C. P. (2019). Capacitação à distância do programa segundo tempo e o lazer: esforços de produção e a busca comunicativa na formação de coordenadores de núcleo. LICERE-Revista do Programa de Pós-graduação Interdisciplinar em Estudos do Lazer, 22(1), 303-330. Doi: https://doi.org/10.35699/1981-3171.2019.12323

Ribeiro, S. P. \& Isayama, H. F. (2015). O lazer na política pública de esporte: uma análise da formação no Programa Segundo Tempo. Revista Brasileira de Ciências e Movimento, 23(1), 103-116. Doi http://dx.doi.org/1018511/0103-1716/rbcmv23n1p103-116

Rodrigues, H. de A.; Rufino, L. G.; Souza Junior, O. M.; Coutinho, S. da S. O Programa Segundo Tempo e seu processo de Capacitação: análises e proposições. Motrivivência, ano XXIV, n. 38, p. 108-122, jun/2012. Doi https://doi.org/10.5007/2175-8042.2012v24n38p108

Starepravo, F. A., Rinaldi, I. P. B., Pizani, J., Seron, T. D., Teixeira, R. T. S., \& de Oliveira, A. A. B. (2012). As Equipes Colaboradoras do Programa Segundo Tempo e suas contribuições para o desenvolvimento de uma política de esporte educacional. Motrivivência, (39), 129-141. Doi https://doi.org/10.5007/2175$8042.2012 \mathrm{v} 24 \mathrm{n} 39 \mathrm{p} 129$

UFGRS. universidade federal do rio grande do sul (2020 a) Publicações: Vídeos. Centro de memórias do Esporte. Memórias do Programa Segundo Tempo. Escola de Educação Física/UFRG. http://www.ufrgs.br/ceme/pst/site/publicacoes/videos

UFRGS. universidade federal do rio grande do sul $(2020$ b) Entrevistas. Centro de Memória do Esporte. Escola de Educação Física/UFRGS. http://www.ufrgs.br/ceme/pst/site/entrevistas

UFRGS. universidade federal do rio grande do sul $(2020$ c). Publicações. Livros. Centro de Memória do Esporte. Escola de Educação Física/UFRGS. http://www.ufrgs.br/ceme/pst/site/publicacoes/livros 